\title{
ЗМІНИ ПОКАЗНИКІВ ОКИСНОГО ГОМЕОСТАЗУ У ХВОРИХ НА КИСЛОТОЗАЛЕЖНІ ЗАХВОРЮВАННЯ ПРИ ЛІКУВАННІ
}

Вступ. Гастроезофрагеальна рефлюксна хвороба (ГЕРХ) та пептична виразка (ПВ) дванадиятипалої кишки (ДПК), які належать до групи кислотозалежних захворювань (КЗ3), залишаються найбільш розповсюдженими серед гастроентерологічної патології. Основним патогенетичним компонентом даних хвороб, що призводить до розвитку ускладнень та рецидивів, $є$ оксидативний стрес. Натепер актуальним $є$ пошук препаратів, здатних впливати на системи антиоксидантного захисту в пацієнтів із КЗ3.

Мета дослідження - вивчити стан систем окисного гомеостазу в пацієнтів із кислотозалежними захворюваннями при лікуванні з використанням базових схем та включенні до базової терапії глутаргіну.

Методи дослідження. Обстежено 28 пацієнтів з ГЕРХ та 23 хворих на ГЕРХ, поєднану з ПВ ДПК. Залежно від терапевтичних схем кожну групу було поділено на 2 підгрупи: пацієнти, які отримували базове лікування, та хворі, до традиційних базових схем яких включали глутаргін. До початку лікування та після його закінчення в крові хворих визначали рівень ТБК-активних продуктів (ТБК-АП), активність супероксиддисмутази (СОД), каталази (Кат), глутатіонпероксидази (ГПО), глутатіонредуктази (ГР), вміст відновленого глутатіону (ВГ).

Результати й обговорення. Аналіз показників пацієнтів із КЗЗ після лікування свідчить про те, що включення глутаргіну до базової терапії в пацієнтів з ГЕРХ та хворих на ГЕРХ, поєднану з ПВ ДПК, призводило до достовірного зниження рівня ТБК-АП як у плазмі, так і в еритроцитах на тлі активації СОД, Кат, показників системи глутатіону. У хворих, які не одержували глутаргіну, дисбаланс у системі окисного гомеостазу не усувався. Фармакологічний ефект цього лікарського засобу пов'язаний з діючими компонентами, які входять до його складу, а саме L-аргініном i L-глутаматом. Антиоксидантні та мембраностабілізувальні властивості L-аргініну реалізуються через NO-регулювальну систему, L-глутамат активує синтез глутатіону.

Висновки. Використання традиційної базової терапії в пацієнтів із кислотозалежними захворюваннями не усуває проявів оксидативного стресу, про що свідчить відсутність достовірних змін показників ліпопероксидації та антиоксидантного захисту. Додавання глутаргіну до базового лікування пацієнтів із гастроезофагеальною рефлюксною хворобою та хворих на гастроезофагеальну рефрлюксну хворобу в поєднанні з пептичною виразкою дванадцятипалої кишки дозволяє нівелювати в них депресію фрерментативної антиоксидантної ланки, збільшити рівень відновленого глутатіону та нормалізувати показники процесів пероксидного окиснення ліпідів.

КЛЮЧОВІ СЛОВА: кислотозалежна патологія; гастроезофагеальна рефрлюксна хвороба; оксидативний стрес; антиоксидантний захист; глутаргін.

ВСТУП. В останні десятиріччя серед гастроентерологічної патології лідируючі позиції зберігає група кислотозалежних захворювань (К33), до яких належать гастроезофрагеальна рефрлюксна хвороба (ГЕРХ) та пептична виразка (ПВ) дванадцятипалої кишки (ДПК) [1, 2].

Досить часте поєднання ПВ ДПК з ГЕРХ призводить до таких ускладнень, як рубцеві зміни стравоходу, кровотеча, срормування стравоходу Барретта, який відомий високим ризиком розвитку аденокарциноми [3].

( ) Л. А. Пономаренко, О. А. Лихолат, О. А. Пономаренко, 2018.
Сучасні наукові дослідження постулюють той фракт, що структурні та функціональні ураження слизової оболонки (СО) верхніх відділів гастродуоденальної зони (ГДЗ) відбуваються при порушенні рівноваги між багатокомпонентною системою захисту СО й агресивними ендо- та екзогенними патогенетичними чинниками $[4,5]$.

Розвиток оксидативного стресу - одна зі складових ланок патогенезу КЗ3. Встановлено, що універсальним механізмом пошкодження та загибелі клітин СО гастродуоденальної зони $є$ 
інтенсифрікація вільнорадикальних процесів 3 подальшим виснаженням антиоксидантних систем організму. Занадто висока швидкість ліпопероксидації призводить до збільшення тонусу судин, викликаючи порушення кровотоку та гіпоксію, що стимулює утворення хемоатрактантів, які залучають у місце пошкодження лейкоцити. Активація фрагоцитів супроводжується "кисневим вибухом" - активним поглинанням кисню 3 навколишніх тканин та генерацією токсичних окиснювачів, які посилюють пошкоджувальну дію гіпоксії на СО гдз. Саме надлишок активних кисневих метаболітів при дефріциті таких антиоксидантів, як відновлений глутатіон та супероксиддисмутаза, призводить до пошкодження ДНК та розвитку аденокарциноми стравоходу [6-8].

У класичних лікувальних схемах КЗ3 головну увагу приділяють пригніченню секреції соляної кислоти з одночасним проведенням ерадикації Helicobacter pylori (HP) при необхідності. Але кількість рецидивів та ускладнень після проведеної терапії спонукає дослідників до пошуку оптимальних методів впливу, які б мали здатність відновлювати порушений прооксидантно-антиоксидантний баланс і підвищувати ефективність лікування $[9,10]$.

Мета дослідження - вивчити стан систем окисного гомеостазу в пацієнтів із кислотозалежними захворюваннями при лікуванні з використанням базових схем та включенні до базової терапії глутаргіну.

МЕТОДИ ДОСЛІДЖЕННЯ. Обстежено 51 хворого віком від 20 до 68 років, яких було поділено на 2 групи залежно від нозологічної фрорми захворювання верхніх відділів шлунково-кишкового тракту. До 1-ї групи ввійшли 28 пацієнтів 3 ГЕРХ, до 2-ї - 23 хворих на ГЕРХ у поєднанні 3 ПВ ДПК. Діагноз підтверджено ендоскопічним та морфологічним методами і за даними рН-моніторингу. Контрольну групу становили 15 осіб, які були зіставні з хворими за віком і статтю, без патології.

Для оцінки ефективності терапії кожну групу, залежно від схеми лікування, було поділено на 2 підгрупи. У 1-й групі кожна підгрупа включала 14 пацієнтів (1а та 1б), у 2-й - 15 (2a) і 8 (2б) хворих відповідно. Базову терапію застосовували в 1а та 2а підгрупах кожної групи. Вона складалась $з$ інгібіторів протонної помпи, при наявності НР - антигелікобактерної терапії, а також (за необхідності) - прокінетиків та антацидів. Пацієнти 16 та 26 підгруп на тлі базової терапії отримували глутаргін по 15-20 мл 4 \% розчину внутрішньовенно протягом 5-6 діб, а потім по 2 пігулки тричі на добу впродовж 7-10 днів. Хво- рі кожної з підгруп були репрезентативні за віком, статтю і супутньою патологією.

Активність пероксидного окиснення ліпідів (ПОЛ) у плазмі та еритроцитах крові визначали за вмістом ТБК-активних продуктів (ТБК-АП) у реакції з тіобарбітуровою кислотою [11]. Стан антиоксидантної системи (АОС) досліджували за рівнем відновленого глутатіону (ВГ), що детермінували за реакцією Еллмана, та за показниками активності фрерментів антипероксидного захисту. Активність каталази (Кат) (КФ 1.11.1.6) оцінювали за реакцією з молібдатом амонію, глутатіонредуктази (ГР) (КФ 1.8.1.7) - за швидкістю окиснення НАДРН, глутатіонпероксидази (ГПО) (КФ 1.11.1.9) - за методом, в основі якого лежить реакція взаємодії реактиву Еллмана із SH-групами [12], супероксиддисмутази (СОД) (КФ 1.15.1.1) - за інгібуванням відновлення нітросинього тетразолію [13].

Статистичну обробку даних здійснювали за допомогою програмного пакета STATISTICA 6.0 (StatSoft, США). Обчислювали середнє арифметичне (М) та стандартну похибку середнього арифрметичного (m). Вірогідними вважали відмінності на рівні $p<0,05$.

РЕЗУЛЬТАТИ Й ОБГОВОРЕННЯ. У нашіЙ попередній роботі [14] встановлено, що у пацієнтів із К33 спостерігалась активація процесів ПОЛ на тлі депресії роботи антиоксидантів як у 1-й, так і в 2-й групах. При цьому визначені зміни були більш виражені у хворих на ГЕРХ, поєднану з ПВ ДПК.

Аналіз ефективності лікування, залежно від застосованої терапії, за станом ПОЛ та АОС виявив ряд особливостей. Так, у пацієнтів 1а підгрупи, які отримували лише базову терапію, після курсу лікування не відзначали достовірних змін кількості ТБК-АП, ВГ, активності досліджуваних ферментів. Включення глутаргіну до базової терапії у хворих Іб підгрупи спричиняло достовірне зниження рівня ТБК-АП як у плазмі (на 23,6 \%, p<0,05), так і в еритроцитах (на $16,4 \%$, р<0,05) на тлі активації СОД (на 14,3\%, p<0,05), Кат (на 7,2 \%, p<0,05), при поповненні пулу ВГ (на 27 \%, р<0,05) відповідно до аналогічних індексів до початку лікування. При дії глутаргіну в пацієнтів Іб підгрупи відмічено тенденцію до підвищення активності ГПО (табл. 1).

Аналогічну динаміку змін показників ліпопероксидації та антиоксидантного захисту при лікуванні спостерігали у хворих 2-ї групи: додавання глутаргіну до базової терапевтичної схеми в пацієнтів 26 підгрупи викликало достовірне зниження кількості ТБК-АП як у плазмі (на $16,3 \%, p<0,05$ ), так і в еритроцитах (на $23 \%$, $p<0,05)$. Зазначене гальмування процесів ПОЛ 
Таблиця 1 - Показники пероксидного окиснення ліпідів і антиоксидантної системи

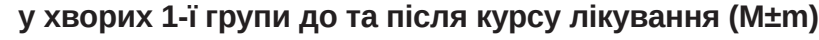

\begin{tabular}{|c|c|c|c|c|c|}
\hline \multirow{2}{*}{ Показник } & \multirow{2}{*}{$\begin{array}{c}\text { Контрольна } \\
\text { група } \\
(n=15)\end{array}$} & \multicolumn{2}{|c|}{$\begin{array}{c}\text { Ia підгрупа } \\
(\mathrm{n}=14)\end{array}$} & \multicolumn{2}{|c|}{$\begin{array}{c}\text { Іб підгрупа } \\
(\mathrm{n}=14)\end{array}$} \\
\hline & & до лікування & $\begin{array}{c}\text { після } \\
\text { лікування }\end{array}$ & до лікування & $\begin{array}{c}\text { після } \\
\text { лікування }\end{array}$ \\
\hline $\begin{array}{l}\text { ТБК-АП у плазмі крові, } \\
\text { нМоль/мл }\end{array}$ & $2,6 \pm 0,19$ & $3,63 \pm 0,30^{\wedge}$ & $3,34 \pm 0,25$ & $3,94 \pm 0,37^{\wedge}$ & $3,01 \pm 0,19^{*}$ \\
\hline $\begin{array}{l}\text { ТБК-АП в еритроцитах, } \\
\text { нМоль/мл }\end{array}$ & $10,98 \pm 0,63$ & $16,02 \pm 0,88^{\wedge}$ & $14,59 \pm 0,85$ & $13,67 \pm 0,67^{\wedge}$ & $11,42 \pm 0,66^{*}$ \\
\hline СОД, ум. од. & $0,109 \pm 0,005$ & $0,071 \pm 0,004^{\wedge}$ & $0,078 \pm 0,006$ & $0,077 \pm 0,004^{\wedge}$ & $0,088 \pm 0,004$ \\
\hline Кат, мМоль $\mathrm{H}_{2} \mathrm{O}_{2} /$ гНв·хв & $4,99 \pm 0,18$ & $4,26 \pm 0,20^{\wedge}$ & $4,29 \pm 0,20$ & $4,47 \pm 0,14^{\wedge}$ & $4,8 \pm 0,15^{*}$ \\
\hline ГП, мкМоль $\mathrm{H}_{2} \mathrm{O}_{2} /$ гНв·Хв & $50,7 \pm 3,83$ & $49,73 \pm 6,2$ & $40,8 \pm 3,62$ & $40,7 \pm 3,9$ & $50,45 \pm 6,2$ \\
\hline ВГ, мМоль/л & $1,92 \pm 0,04$ & $1,89 \pm 0,07$ & $1,92 \pm 0,07$ & $1,67 \pm 0,08^{\wedge}$ & $2,12 \pm 0,10^{*}$ \\
\hline ГР, нМольНАДРН/ГНв·хв & $0,28 \pm 0,01$ & $0,256 \pm 0,01$ & $0,27 \pm 0,01$ & $0,234 \pm 0,01^{\wedge}$ & $0,255 \pm 0,01$ \\
\hline
\end{tabular}

Примітки. Тут і в таблиці 2:

1. ^ - вірогідність відмінностей показників порівняно з контрольною групою $(p<0,05)$.

2. * - вірогідність відмінностей показників до та після лікування $(p<0,005)$.

супроводжувалось достовірною активацією СОД (на $21 \%, p<0,05)$, Кат (на $13 \%, p<0,05)$, ГПО (на $41 \%, p<0,05)$, ГР (на $18 \%, p<0,05)$ зі збільшенням пулу ВГ (на $18 \%, p<0,05)$. У хворих, які не одержували глутаргіну, спостерігали зменшення рівня ТБК-АП у плазмі (на $10 \%$, р<0,05), але дисбаланс у системі окисного гомеостазу не усувався (табл. 2).

Відомим патогенетичним чинником при ураженні СО ГДЗ $є$ порушення регіонарного кровотоку. Важливим фрактором, що визначає внутрішньосудинний компонент мікроциркуляції і постачання до тканин кисню, є реологічні властивості крові, які залежать від фрункціональної повноцінності еритроцитів. Унікальні реологічні властивості еритроцитів зумовлені спеціалізованими цитоскелетними білками та мембранними поліненасиченими жирними кислотами, що містяться у високій концентрації. Наявність високої концентрації молекулярного кисню та заліза в складі гемової групи еритроцитів несе потенційну загрозу утворення надлишку активних кисневих метаболітів. Маючи власну потужну антиокисну систему, еритроцити здатні забезпечува- ти мобільний захист від радикалів, що утворюються в організмі в цілому. Окисне ураження білків та мембранних ліпідів впливає на метаболізм еритроцитів як переносників кисню, що $€$ однією з причин розвитку гіпоксичних змін у СО ГДЗ.

3 огляду на результати наших досліджень, глутаргін здатний впливати на систему антиоксидантного захисту еритроцитів у пацієнтів із КЗ3. Фармакологічний ефрект зазначеного лікарського засобу пов'язаний з діючими компонентами, які входять до його складу, а саме L-аргініном і L-глутаматом. Так, L-аргінін $€$ інгібітором як початкових, так і кінцевих стадій пОЛ завдяки здатності безпосередньо вступати в реакцію із супероксидним аніон-радикалом. Антиоксидантні та мембраностабілізувальні властивості L-apгініну також реалізуються через NO-регулювальну систему. Глутамінова кислота і ряд її метаболітів, змінюючи активність сросфорилази $\mathrm{A}_{2}$, сприяють видаленню токсичних продуктів переокиснених жирнокислотних залишків фоосфоліпідів. Як глутаматовмісна сполука глутаргін активує синтез глутатіону, сприяє активації глута-

Таблиця 2 - Показники пероксидного окиснення ліпідів і антиоксидантної системи у хворих 2-ї групи до та після курсу лікування (M士m)

\begin{tabular}{|c|c|c|c|c|c|}
\hline \multirow{2}{*}{ Показник } & \multirow{2}{*}{$\begin{array}{c}\text { Контрольна } \\
\text { група } \\
(n=15)\end{array}$} & \multicolumn{2}{|c|}{$\begin{array}{l}\text { IIa підгрупа } \\
(n=15)\end{array}$} & \multicolumn{2}{|c|}{$\begin{array}{c}\text { ІІб підгрупа } \\
(\mathrm{n}=8)\end{array}$} \\
\hline & & до лікування & $\begin{array}{c}\text { після } \\
\text { лікування }\end{array}$ & до лікування & $\begin{array}{c}\text { після } \\
\text { лікування }\end{array}$ \\
\hline $\begin{array}{l}\text { ТБК-АП у плазмі крові, } \\
\text { нМоль/мл }\end{array}$ & $2,6 \pm 0,19$ & $3,93 \pm 0,40^{\wedge}$ & $3,54 \pm 0,32^{*}$ & $3,87 \pm 0,29^{\wedge}$ & $3,42 \pm 0,31^{*}$ \\
\hline $\begin{array}{l}\text { ТБК-АП в еритроцитах, } \\
\text { нМоль/мл }\end{array}$ & $10,98 \pm 0,63$ & $14,59 \pm 0,76^{\wedge}$ & $14,59 \pm 0,85$ & $16,92 \pm 0,75^{\wedge}$ & $13,02 \pm 0,60^{*}$ \\
\hline СОД, ум. од. & $0,109 \pm 0,005$ & $0,068 \pm 0,004^{\wedge}$ & $0,079 \pm 0,01$ & $0,065 \pm 0,003^{\wedge}$ & $0,079 \pm 0,004$ \\
\hline Кат, мМоль $\mathrm{H}_{2} \mathrm{O}_{2} /$ гНв·хв & $4,99 \pm 0,18$ & $4,06 \pm 0,16^{\wedge}$ & $4,35 \pm 0,25$ & $4,13 \pm 0,12^{\wedge}$ & $4,69 \pm 0,17^{*}$ \\
\hline ГП, мкМоль $\mathrm{H}_{2} \mathrm{O}_{2} /$ гНв·хв & $50,7 \pm 3,83$ & $39,3 \pm 6,99$ & $43,63 \pm 7,30$ & $37,22 \pm 3,89^{\wedge}$ & $52,48 \pm 3,67^{*}$ \\
\hline ВГ, мМоль/л & $1,92 \pm 0,04$ & $1,71 \pm 0,08^{\wedge}$ & $1,78 \pm 0,08$ & $1,67 \pm 0,07^{\wedge}$ & $1,98 \pm 0,09^{*}$ \\
\hline ГР, нМольНАДРН/гНв·хв & $0,28 \pm 0,01$ & $0,25 \pm 0,01$ & $0,25 \pm 0,01$ & $0,22 \pm 0,01^{\wedge}$ & $0,26 \pm 0,006^{*}$ \\
\hline
\end{tabular}


тіонпероксидази. 3 глутамінової кислоти шляхом переамінування або дезамінування утворюються кетокислоти, які стимулюють цикл Кребса, продукуючи необхідну для клітин енергію. При цьому L-аргінін підсилює активуючий вплив L-глутамату [15].

ВИСНОВКИ. Застосування традиційної базової терапії в пацієнтів із кислотозалежними захворюваннями не усує проявів оксидативного стресу, про що свідчить відсутність достовірних

\section{СПИСОК ЛІТЕРАТУРИ}

1. Update on the epidemiology of gastro-oesophageal reflux disease: a systematic review / H. B. El-Serag, S. Sweet, C. C. Winchester, J. Dent // Gut. - 2014. - 63, No. 6. - P. 871-880.

2. Lanas A. Peptic ulcer disease / A. Lanas, F. K. L. Chan // The Lancet. - 2017. - 390, No. 10094. P. 613-624.

3. Комарчук В. В. Оценка качества жизни пациентов при осложненных фрормах язвенной болезни в сочетании с рефлюксной болезнью / В.В.Комарчук // Клініч. хірургія. - 2012. - № 10. - С. 62-64.

4. Yandrapu $\mathrm{H}$. Protective factors of the gastric and duodenal mucosa: An overview / H. Yandrapu, J. Sarosiek1 // Current Gastroenterology Reports. - 2015. 17, No. 6. - P. 24.

5. Гастроинтестинальный барьер: структурные и молекулярные детерминанты в норме и при ульцерогенезе / Э. Ф. Баринов, П. Г. Кондратенко, О. Н. Сулаева [и др.] // Укр. журн. хірургії. - 2013. - № 4 (23). C. 96-104.

6. Oxidative stress: an essential factor in the pathogenesis of gastrointestinal mucosal diseases / A. Bhattacharyya, R. Chattopadhyay, S. Mirta [et al.] // Physiol. Rev. - 2014. - 94, No. 2. - P. 329-354.

7. Kwiecien S. Lipid peroxidation, reactive oxygen species and antioxidative factors in the pathogenesis of gastric mucosal lesions and mechanism of protection against oxidative stress - induced gastric injury / S. Kwiecien, K. Jasnos, M. Magierowski [et al.] // Journal of Physiology and Pharmacology. - 2014. - 65, No. 5. P. 613-622.

\section{REFERENCES}

1. El-Serag, H.B., Sweet, S., Winchester, C.C., \& Dent, J. (2014). Update on the epidemiology of gastrooesophageal reflux disease: a systematic review. Gut, 63 (6), 871-880.

2. Lanas, A., \& Chan, F.K.L. (2012). Peptic ulcer disease. The Lancet, 390, (10094), 613-624. змін показників ліпопероксидації та антиоксидантного захисту. Додавання глутаргіну до базового лікування в пацієнтів із гастроезофрагеальною рефлюксною хворобою та хворих на гастроезофрагеальну рефлюксну хворобу в поєднанні з пептичною виразкою дванадцятипалої кишки дозволяє нівелювати депресію ферментативної антиоксидантної ланки, збільшити рівень відновленого глутатіону та нормалізувати показники процесів пероксидного окиснення ліпідів.

8. Роль оксидативного стресса в патогенезе гастроэзофрагеальной ресрлюксной болезни / Н. Н. Буторин, Т. Б. Бичурина, А. В. Васютин [и др.] // Клинич. гастроэнтерология. - 2015. - № 3. - С. 17-20.

9. Freedberg D. E. The risks and benefits of long-term use of proton pump inhibitors: expert review and best practice advice from the American Gastroenterological Association / D. E. Freedberg, S. Lawrence, Yu-Xiao Yang // Gastroenterology -2017. - No. 152. - P. 706-715.

10. Vitamin E: a potential therapy for gastric mucosal injury / Y. Kamisah, H. M. Qodriyah, K. H. Chua [et al.] // Pharm. Biol. - 2014. - 52, No. 12. - P. 1591-1597.

11. Овсяннікова Л. М. Біохімічні та біофізичні методи оцінки порушень окислювального гомеостазу в осіб, що зазнали радіаційного впливу внаслідок аварії на ЧАЕС : метод. рек. / Л. М. Овсяннікова, С. М. Альохіна, О. В. Дробінська. - К., 1999. - 20 с.

12. Современные проблемы биохимии. Методы исследований: учеб. пособ. / [Е. В. Барковский, С. Б. Бокуть, А. Н. Бородинский и др.]. - Минск : Выш. шк., 2013. - 491 c.

13. Переслегина И. А. Активность антиоксидантных ферментов слюны здоровых детей / И. А. Переслегина // Лаб. дело. - 1989. - № 11. - С. 20-23.

14. Пономаренко Л. А. Особливості систем антиоксидантного захисту у хворих із кислотозалежною патологією / Л. А. Пономаренко, О. Л. Лихолат, О. А. Пономаренко // Досягнення біології та медицини. -2011 . - 17, № 1. - С. 33-37.

15. Бабак О. Я. Глутаргин - фрармакологическое действие и клиническое применение / О. Я. Бабак, В. М. Фролов, Н. В. Харченко. - Х. : Элтон-2, 2005. $45 \mathrm{c}$.

3. Komarchuk, V.V. (2012). Otsenka kachestva zhizni patsiyentov pri oslozhnennykh formakh yazvennoy bolezni v sochetanii s reflyuksnoy boleznyu [Assessment of the quality of life of patients with complicated forms of peptic ulcer in combination with reflux disease]. Klinichna hirurhiia - Clinical Surgery, 10, 62-64 [in Russian]. 
4. Yandrapu, H. \& Sarosiek, J. (2015). Protective factors of the gastric and duodenal mucosa: An overview. Current Gastroenterology Reports,17 (6), 24.

5. Barinov, E.F., Kondratenko, P.G., Sulayeva, O.N., Yarikov, S.O., \& Delyy, V.Yu. (2013). Gastrointestinalnyy baryer: strukturnyye i molekulyarnyye determinanty $\mathrm{v}$ norme i pri ultserogeneze [Gastrointestinal barrier: structural and molecular determinants in norm and in ulcerogenesis]. Ukrainskyi zhurnal khirurhii - Ukrainian Journal of Surgery, 23 (4), 96-104 [in Russian].

6. Bhattacharyya, A., Chattopadhyay, R., Mitra, S., \& Crowe, S.E. (2014). Oxidative stress: an essential factor in the pathogenesis of gastrointestinal mucosal diseases. Physiological Reviews, 94 (2), 329-354.

7. Kwiecien, S., Jasnos, K., Magierowski, M., Sliwowski, Z., Pajdo, R., Brzozowski, B., Mach, T., Wojcik, D., \& Brzozowski, T. (2014). Lipid peroxidation, reactive oxygen species and antioxidative factors in the pathogenesis of gastric mucosal lesions and mechanism of protection against oxidative stress - induced gastric injury. Journal of Physiology and Pharmacology, 65 (5), 613-622.

8. Butorin, N.N., Bichurina, T.B., Vasjutin, A.V., Solodenova, M.E., Onuchina, E.V., Tonkikh, Yu.L., \& Cukanov, V.V. (2015). Rol oksidativnogo stressa v patogeneze gastroezofagealnoy refliuksnoy bolezni [Role of oxidative stress in the pathogenesis of gastroesophageal reflux disease]. Klinicheskaya gastroenterologiya Clinical Gastroenterology, 3, 17-20 [in Russian].

9. Freedberg, D.E., Lawrence, S. \& Yang, Yu-Xiao (2017). The risks and benefits of long-term use of proton pump inhibitors: expert review and best practice advice from the American Gastroenterological Association. Gastroenterology, 152, 706-715.
10. Kamisah, Y., Qodriyah, H.M., Chua, K.H., Nur Azlina, M.F. (2014) Vitamin E: a potential therapy for gastric mucosal injury. Pharmaceutical Biology, 52 (12), 1591-1597.

11. Ovsiannikova, M.M., Alokhina, S.M., \& Drobinska, O.V. (1999). Biokhimichni ta biofizychni metody otsinky porushen okysliuvalnoho homeostazu v osib, shcho zaznaly radiatsiinoho vplyvu vnaslidok avarii na ChAES (metodychni rekomendatsii) [Biochemical and biophysical methods for evaluating the disturbances of oxidative homeostasis in persons who have undergone radiation influence as a result of the Chernobyl accident (methodical recommendations)]. Kyiv [in Russian].

12. Barkovskiy, E.V., Bokut, S.B., Borodinskiy, A.N., Buko, V.U., Valentyukevich , O.I., Gritsuk, A.I., \& Chirkin, A.A. (2013). Sovremennye problemy biokhimii. Metody issledovaniy [Modern problems of biochemistry. Research Methods]. Minsk: Vyshaya Shkola [in Russian].

13. Pereslegina, I.A. (1989). Aktivnost antioksidantnykh fermentov slyuny u zdorovykh detey [Activity of antioxidant saliva enzymes in healthy children]. Laboratornoe delo - Laboratory Work, 11, 20-23 [in Russian].

14. Ponomarenko, L.A., Lykholat, O.A., \& Ponomarenko, O.A. (2011). Osoblyvosti system antyoksydantnoho zakhystu u khvorykh iz kyslotozalezhnoiu patolohiieiu [Features of antioxidant protection systems in patients with acid-dependent pathology.] Dosiahnennia biolohii ta medytsyny - Achievements of Biology and Medicine, 1 (17), 33-37 [in Ukrainian].

15. Babak, O.Ya., Frolov, V.M., \& Harchenko, N.V. (2005). Glutargin - farmakologicheskoe deystvie i klinicheskoe primenenie [Glutargin - pharmacological action and clinical application]. Kharkov: Elton-2 [in Russian].

Л. А. Пономаренко ${ }^{1}$, Е. А. Лихолат ${ }^{2}$, А. А. Пономаренко ${ }^{3}$ ДНЕПРОПЕТРОВСКАЯ ОБЛАСТНАЯ ДЕТСКАЯ КЛИНИЧЕСКАЯ БОЛЬНИЦА ДОС 1 УНИВЕРСИТЕТ ТАМОЖЕННОГО ДЕЛА И ФИНАНСОВ ${ }^{2}$, ДНЕПР КАМЬЯНСКАЯ ГОРОДСКАЯ БОЛЬНИЦА № $9^{3}$

\section{ИЗМЕНЕНИЯ ПОКАЗАТЕЛЕЙ ОКИСЛИТЕЛЬНОГО ГОМЕОСТАЗА У БОЛЬНЫХ КИСЛОТОЗАВИСИМЫМИ ЗАБОЛЕВАНИЯМИ ПРИ ЛЕЧЕНИИ}

\section{Резюме}

Вступление. Гастроэзофрагеальная рефрлксная болезнь (ГЭРБ) и пептическая язва (ПЯ) двенадцатиперстной кишки (ДПК), принадлежащие к группе кислотозависимых заболеваний (КЗ3), остаются наиболее распространенными среди гастроэнтерологической патологии. Основным патогенетическим компонентом данных заболеваний, который приводит к развитию осложнений и рецидивов, является оксидативный стресс. На данный момент актуальным является поиск препаратов, способных влиять на системы антиоксидантной защиты у пациентов с КЗ3.

Цель исследования - изучить состояние систем окислительного гомеостаза у пациентов с кислотозависимыми заболеваниями при лечении с использованием базовых схем и включении в базовую терапию глутаргина.

Методы исследования. Обследованы 28 пациентов с ГЭРБ и 23 больных ГЭРБ, сочетанной с ПЯ ДПК. В зависимости от терапевтических схем каждая группа была разделена на 2 подгруппы: пациенты, получающие базовое лечение, и больные, в традиционные базовые схемы которых включали глутаргин. До начала лечения и после его завершения в крови больных определяли уровень ТБК-активных продуктов (ТБК-АП), активность супероксиддисмутазы (СОД), каталазы (Кат), глутатионпероксидазы (ГПО), глутатионредуктазы (ГР), содержание восстановленного глутатиона (ВГ). 
Результаты и обсуждение. Анализ показателей пациентов с КЗЗ после лечения свидетельствует о том, что включение глутаргина в базовую терапию у пациентов с ГЭРБ и больных ГЭРБ, сочетанной с ПЯ ДПК, приводило к достоверному снижению уровня ТБК-АП как в плазме, так и в эритроцитах на фоне активации СОД, Кат, показателей системы глутатиона. У больных, которые не получали глутаргина, дисбаланс в системе окислительного гомеостаза не устранялся. Фармакологический эфрфект этого лекарственного средства связан с действующими компонентами, входящими в его состав, а именно L-аргинином и L-глутаматом. Антиоксидантные и мембраностабилизирующие свойства L-аргинина реализируются посредством NO-регулирующей системы, L-глутамат активирует синтез глутатиона.

Выводы. Использование традиционной базовой терапии у пациентов с кислотозависимыми заболеваниями не устраняет проявлений оксидативного стресса, о чем свидетельствует отсутствие достоверных изменений показателей липопероксидации и антиоксидантной защиты. Включение глутаргина в базовое лечение пациентов с гастроэзофрагеальной рефлюксной болезнью и больных гастроэзофрагеальной рефрюксной болезнью, сочетанной с пептической язвой двенадцатиперстной кишки, позволяет нивелировать у них депрессию фрерментативного антиоксидантного звена, увеличить уровень восстановленного глутатиона и нормализировать показатели процессов перекисного окисления липидов.

КЛЮЧЕВЫЕ СЛОВА: кислотозависимая патология; гастроэзофрагеальная рефлюксная болезнь; оксидативный стресс; антиоксидантная защита; глутаргин.

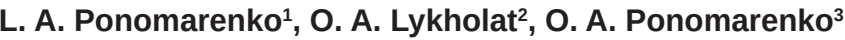
DNIPROPETROVSK REGIONAL CHILDREN'S CLINICAL HOSPITAL ${ }^{1}$ UNIVERSITY OF CUSTOMS AND FINANCE ${ }^{2}$ KAMIANSKE CITY HOSPITAL NO. $9^{3}$

\section{CHANGES OF INDICATORS OF OXIDATIVE STRESS IN PATIENTS WITH ACID-DEPENDABLE DISEASES IN TREATMENT}

\section{Summary}

Introduction. Gastroesophageal reflux disease (GERD) and peptic ulcer (PU) of the duodenum belonging to the group of acid-dependent diseases $(A D D)$ remain the most common among gastroenterological pathologies. The main pathogenic component of the diseases, leading to the development of abrasions and relapses, is oxidative stress. The search for drugs that can effect the antioxidant defense systems in patients with ADD is actual.

The aim of the study - to investigate the state of oxidative homeostasis systems in patients with acid-dependent diseases during treatment using basic regimens and adding glutargin to the basic therapy.

Research Methods. 28 patients with GERD and 23 patients with GERD combined with PU duodenum were examined. Depending on the therapeutic regimens, each group is divided into 2 sub-groups: patients receiving basic treatment, and patients with treatment on traditional scheme with adding glutargin. Before and after the treatment, TBA-active products, activity of superoxide dismutase (SOD), catalase (Cat), glutathione peroxidase (GPO), glutathione reductase (GR), the content of reduced glutathione (GSH) were determined in the blood of the patients.

Result and Discussion. Analysis of the treatment data for patients with ADD indicates that the inclusion of glutargin in the basic therapy in patients with GERD and in patients with GERD combined with PU duodenum led to a significant decrease in TBA-active products both plasma and erythrocytes against the background of activation of SOD, Cat, indicators of the glutathione system. In patients who did not receive glutargin, the imbalance in the oxidative homeostasis system was not eliminated. The pharmacological effect of glutargin is related to the active ingredients that make up its composition, namely, L-arginine and L-glutamate. Antioxidant and membrane stabilizing properties of L-arginine are realized by means of NO-regulating system, L-glutamate activates the synthesis of glutathione.

Conclusions. The use of traditional basic therapy in patients with acid-dependent diseases did not eliminate manifestations of oxidative stress, as evidenced by the lack of reliable changes in the indices of lipid peroxidation systems and antioxidant protection. The inclusion of glutargin in the basic treatment of patients with gastroesophageal reflux disease and patients with gastroesophageal reflux disease combined with peptic ulcer of the duodenal ulcer allowed them to level out the depression of the enzyme antioxidant link, to raise recovered glutathione level and normalize lipoperoxidation processes parameters.

KEY WORDS: acid-dependent pathology; gastroesophageal reflux disease; oxidative stress; antioxidant protection; glutargin.

Отримано 29.06.18

Адреса для листування: Л. А. Пономаренко, Дніпропетровська обласна дитяча клінічна лікарня ДОР, вул. Космічна, 13, Дніпро, 49100, Україна, e-mail: kdl17lud@gmail.com. 